\section{Efficacy of Plant Growth Retardants as Preplant Bulb Dips for Height Control in LA and Oriental Hybrid Lilies}

\author{
Anil P. Ranwala, \\ Garry Legnani, \\ Mary Reitmeier, \\ Barbara B. Stewart, and \\ William B. Miller
}

Additional indeX words. ancymidol, Lilium, paclobutrazol, plant growth regulators, uniconazole

Summary. We evaluated preplant bulb dips in three commercial plant growth retardants [ancymidol (A-Rest), paclobutrazol (Bonzi), and uniconazole (Sumagic)] for height control in seven oriental hybridlily (Lilium) cultivars (Aubade, Berlin, Casa Blanca, Muscadet, Sissi, Star Gazer, and Tom Pouce), and seven LA-hybridlily [hybrids resulting from crosses between easter lily (Lilium longiflomm) and Asiatic hybrids] cultivars (Aladdin's Dazzle, Best Seller, Cebeco Dazzle, Royal Dream, Royal Parade, Royal Perfume, and Salmon Classic) grown in containers. A l-min dip into a range of concentrations of each product was used to determine the optimum concentrations for height control. The results indicate thatbulb dips, especially with uniconazole and paclobutrazol, can be a highly effective means of height control in hybrid lilies. Cultivars varied in their response to growth retardant treatments. In general, LA-hybrid lilies were much more responsive to the growth retardant treatments than oriental hybrids and

Department of Horticulture, Cornell University, Ithaca, NY 14853.

Use of trade names does not imply endorsement of the products named or criticism of similar ones not named. We are grateful to the Royal Dutch Wholesalers' Association for Flowerbulbs and Nursery Stock, SePro, Inc., Uniroyal Chemical Company, and Valent USA for financial aid and materials support, and to the greenhouse staff of the Kenneth Post Laboratory of Cornell University for plant care. required lower rates for comparable height control.Delays in flowering, increased bud abortion and leafyellowing were observed only with high concentrations of uniconazole or paclobutrazol where the height reduction was also too excessive for a commercially acceptable crop.

$\mathrm{H}$ ybrid lilies are becoming increasingly popular as containerized (pot) plants in North America. Height control is a crucial element in pot culture of lilies in order to obtain a plant that is in aesthetic proportion to the size of the container (Sachs et al., 1976), and for the ease of handling and better volume utilization during transportation. While cultivars suited for pot culture without growth regulation exist, growers still tend to adapt cut flower cultivars for pot plant production. Most of these cultivars produce long stems, which makes height control an important concern when forcing these cultivars as pot plants. The challenge for the pot lily grower is to produce a shorter plant with minimal effects on bud count, flowering characteristics, and forcing time while maintaining excellent postharvest characteristics.

Height control in lilies can be achieved with several techniques including negative DIF (night temperature greater than day temperature) (Erwin and Heins, 1990), photoperiod control, reduction of far red light (Blom et al., 1995), and chemical plant growth retardants (PGRs) (Lewis and Gilbertz, 1987; Bailey and Miller 1989; Holcomb et al., 1991). The relative ease and flexibility of application make PGRs a popular choice for height control in lilies. Plant growth retardants are especially advantageous in situations where different crops that require different degrees of growth control are forced in the same greenhouse.

Foliar sprays and substrate drenches are the most common techniques of applying PGRs to lilies. These techniques have inherent disadvantages such as high labor costs, possible phytotoxicity and shorter residual activity in the case of foliar sprays, and reduced effectiveness of drenches in media containing pine bark. Preplant bulb dips into PGR solutions are known to be effective (Simmonds and Cumming 1977; Larson et al., 1987), but are less commonly used in industry. Advantages of preplant bulb dips over the other meth- ods of PGR application are time and labor savings, early control of plant height, accurate dosages and reasonable cost. Disadvantages of dips, as outlined by Larson et al. (1987) include cultivar variability of responsiveness, nonuniformity of treatments across seasons, and treatments are given well before knowing the need for height control. Furthermore, disposal of used dip solution may be problematic.

Most of the research reported on lily PGR dips have been limited to easter lily using ancymidol (Larson et al., 1987; Lewis and Gilbertz, 1987; Lewis and Lewis, 1980, 1982; Simmonds and Cumming, 1977, 1978). Although new PGRs such as uniconazole and paclobutrazol are very effective as sprays and drenches for height control in both easter lilies and hybrid lilies (Bailey and Miller, 1989; Jiao et al., 1990), published information on the effectiveness of these chemicals as preplant dips in hybrid lilies is limited (Choi et al., 1998; Liu and Heins, 1995).

The objective of the current research was to evaluate the effectiveness of uniconazole, paclobutrazol, and ancymidol as preplant bulb dips in seven cultivars each of oriental and LA-hybrid lily groups grown as pot plants.

\section{Materials and methods}

1999 EXPeriments. Experiments were conducted from March to June 1999 in fan and pad cooled, glass greenhouses at Cornell University, Ithaca, N.Y. Precooled lily bulbs grown in the Netherlands were obtained from a commercial source, and stored in moist peat moss in the original packaging at 3 to $4{ }^{\circ} \mathrm{C}\left(37\right.$ to $\left.39^{\circ} \mathrm{F}\right)$ until used (less than 2 weeks). Six oriental hybrid cultivars (Aubade, Berlin, Sissi, Star Gazer, Tom Pouce, and Muscadet) and six LAhybrid cultivars (Royal Perfume, Best Seller, Royal Dream, Aladdin's Dazzle, Salmon Classic, and Royal Parade) were used. The bulb size (circumference) of oriental hybrid lily cultivars was 16 to 18 $\mathrm{cm}$ (6.3 to 7.1 inches), except for 'Berlin' and 'Star Gazer' [ 14 to $16 \mathrm{~cm}$ (5.5 to 6.3 inches)] while LA-hybrid lily cultivars were 14 to $16 \mathrm{~cm}$, except for 'Best Seller' [ 12 to $14 \mathrm{~cm}$ (4.7 to 5.5 inches)]. At the time of dip treatments, LA-hybrid bulbs were, on average, sprouted to 1.5 to $2.0 \mathrm{~cm}(0.6$ to 0.8 inches) except 'Royal Perfume' which had $4.5 \mathrm{~cm}$ (1.8 inches) long sprouts, while all oriental hybrids were sprouted to less than $1.0 \mathrm{~cm}(0.4$ inches $)$. 
Growth regulator solutions used for dipping treatments in this experiment were Bonzi (Uniroyal Chemical Co., Middlebury, Conn.) $[50,100,200$ or $300 \mathrm{mg} \cdot \mathrm{L}^{-1}$ (ppm) a.i. paclobutrazol], Sumagic (Valent USA Corp., Walnut Creek, Calif.) $(2.5,5.0,7.5$ or 10.0 $\mathrm{mg} \cdot \mathrm{L}^{-1}$ a.i. uniconazole], or A-Rest (SePRO Corp., Carmel, Ind.) (11, 22 or $33 \mathrm{mg} \cdot \mathrm{L}^{-1}$ a.i. ancymidol]. Five bulbs were immersed for $1 \mathrm{~min}$ in $1 \mathrm{~L}(34 \mathrm{fl}$ $\mathrm{oz}$ ) of the growth regulator solution. Bulbs immersed in water served as the controls. Fresh growth regulator solution was used for each cultivar $\times$ PGR combination. After dipping, bulbs were drained and held at $20^{\circ} \mathrm{C}\left(68^{\circ} \mathrm{F}\right)$ for 3 to $5 \mathrm{~h}$ before planting in $15.2 \mathrm{-cm}$ diameter (6-inch) pots using a commercial soilless media (Metro mix 360; Scotts, Marysville, Ohio).

In the greenhouse, plants were spaced $20 \times 20 \mathrm{~cm}(8$ inches $)$ (center to center), and were fertilized at each watering with a mixture containing $20 \mathrm{~N}-$ 4.4P-16.6K (Scotts Co., Marysville, Ohio) at $200 \mathrm{mg} \cdot \mathrm{L}^{-1}$ nitrogen, alternated with calcium nitrate plus potassium nitrate at the concentration of 200 $\mathrm{mg} \cdot \mathrm{L}^{-1}$ each of nitrogen and potassium. All plants received full natural sunlight in the greenhouse. A set point temperature of $22 / 18{ }^{\circ} \mathrm{C}\left(72 / 64^{\circ} \mathrm{F}\right)$ (vent/ heat) was used during the experiment. Standard insect control (imidacloprid) and other cultural practices were followed. No fungicides were used.

Data recorded included the dates of emergence, visible bud and anthesis (when the first flower opened), weekly height measurements (pot rim to top of plant) from emergence to anthesis, and the number of leaves, chlorotic leaves, buds and aborted buds at anthesis.

2000 EXPERIMENTS. Experiments were conducted from Apr. to June 2000 in Cornell University greenhouses. Precooled lily bulbs of six oriental hybrid lily cultivars and four LA-hybrid cultivars grown in the Netherlands were obtained from a commercial source, and held in the original packaging at 3 to $4{ }^{\circ} \mathrm{C}$ until used (less than 2 weeks). Oriental hybrid lily cultivars used were (bulbcircumference in parenthesis) 'Berlin' (14 to $16 \mathrm{~cm}$ ), 'Casa Blanca' ( 14 to $16 \mathrm{~cm}$ ), 'Sissi' (16 to $18 \mathrm{~cm}$ ), 'Star Gazer' (12 to $14 \mathrm{~cm}, 14$ to $16 \mathrm{~cm}$, and 16 to $18 \mathrm{~cm}$ ), 'Tom Pouce' (16 to 18 $\mathrm{cm}$ ), and 'Muscadet' (14 to $16 \mathrm{~cm}$ ). LAhybrid cultivars used were 'Cebeco Dazzle' ( 14 to $16 \mathrm{~cm})$, 'Royal Perfume' (14 to $16 \mathrm{~cm}$ ), 'Salmon Classic' (12 to $14 \mathrm{~cm}$ ), and 'Royal Parade' (12 to 14 $\mathrm{cm})$. At the time of dip treatments, all LA-hybrid bulbs were, on average, sprouted to about $5.0 \mathrm{~cm}$ (2.0 inches), and the oriental hybrids to $2.5 \mathrm{~cm}(1.0$ inch).

The PGR treatments were essentially the same as in 1999 except that ancymidol was used only at the 33 $\mathrm{mg} \cdot \mathrm{L}^{-1}$ rate. In 2000 , plants were grown with a greenhouse setpoint of $17^{\circ} \mathrm{C}(63$ $\left.{ }^{\circ} \mathrm{F}\right)$ (day and night). While the greenhouse had fan and pad cooling, daytime temperatures frequently exceeded the set point. Spacing, fertilizer and other cultural practices were same as in 1999 experiment. Data were collected at flowering.

Data analysis. Data for each cultivar were subjected to analysis of variance separately using a completely randomized design with five replicates (plants) per treatment. Duncan's multiple range test was used for mean separation.

\section{Results}

1999 EXPeriments. Bulb-dip treatments did not affect the number of days for shoot emergence in any cultivar. Within the oriental group, control plants of 'Aubade', 'Berlin', 'Muscadet', 'Sissi', 'Star Gazer', and 'Tom Pouce' flowered 90, 84, 92, 98, 94, and $93 \mathrm{~d}$ after planting (DAP), respectively. Only a slight delay in flowering ( 2 to $3 \mathrm{~d}$ ) was caused by the highest concentrations of paclobutrazol or uniconazole in 'Aubade', 'Sissi', and 'Star Gazer'. Growth regulator treatments did not cause any significant flowering delay in the other oriental lily cultivars. In the LA-hybrid group, control plants of 'Aladdin's Dazzle', 'Best Seller', 'Royal Dream', 'Royal Parade', 'Royal Perfume', and 'Salmon Classic' flowered at $66,58,61,62,59$, and $53 \mathrm{DAP}$, respectively. Only 2 to $3 \mathrm{~d}$ delay in flowering occurred with the highest concentrations of paclobutrazol $\left(300 \mathrm{mg} \cdot \mathrm{L}^{-1}\right)$ or uniconazole $\left(10.0 \mathrm{mg} \cdot \mathrm{L}^{-1}\right)$ in 'Aladdin's Dazzle', 'Royal Dream', and 'Royal Parade', while flowering date was not affected by any PGR treatment in the

Table 1. Effects of 1-min bulb dip in paclobutrazol (Bonzi), uniconazole (Sumagic), and ancymidol (A-Rest) on plant height (in centimeters, measured from pot rim to top of plant) of six oriental hybrid lily cultivars at flowering (1999 experiment). Bulb size (circumference) of each cultivar is given in parentheses; $2.54 \mathrm{~cm}=1.0 \mathrm{inch}$.

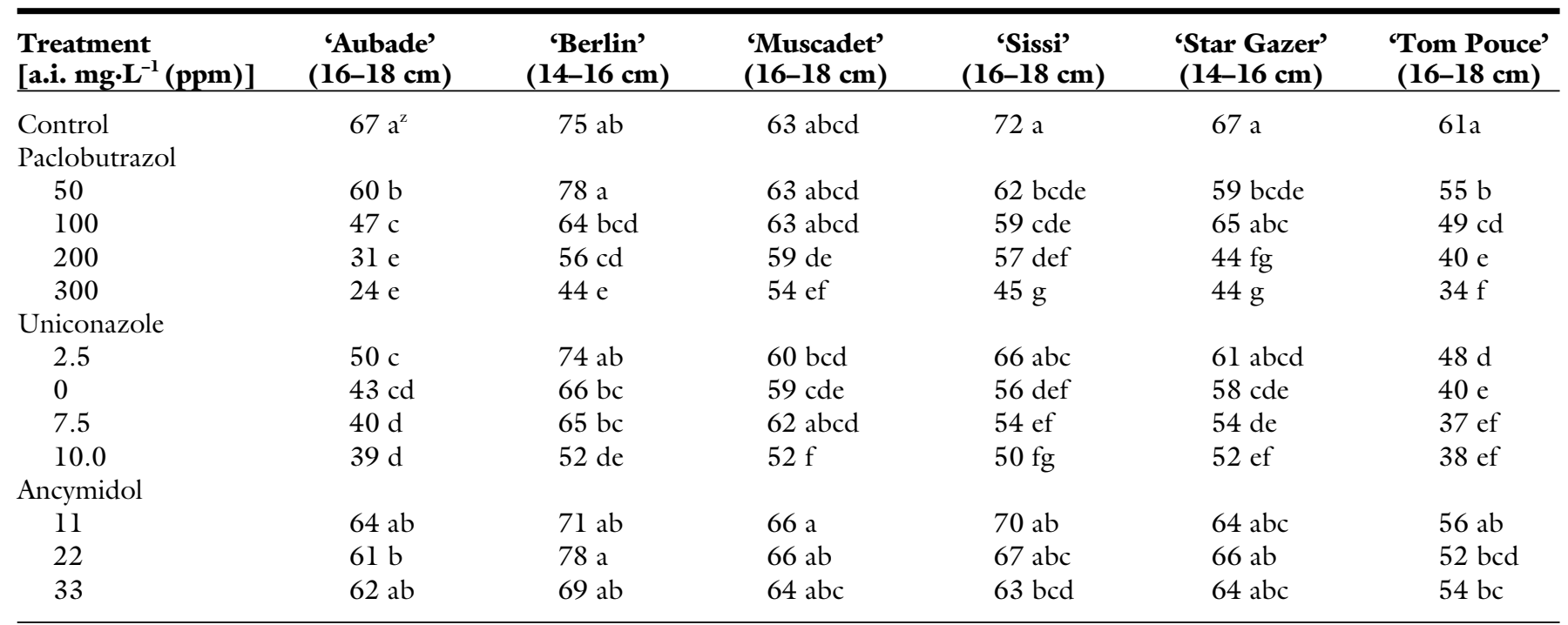

${ }^{\mathrm{z}}$ Mean separation within columns by Duncan's multiple range test $(P \leq 0.05)$. Values are means of five replications (plants). 
Table 2. Effects of 1-min bulb dip in paclobutrazol (Bonzi), uniconazole (Sumagic), and ancymidol (A-Rest) on plant height (in centimeters, measured from pot rim to top of plant) of six LA-hybrid lily cultivars at flowering (1999 experiment). Bulb size (circumference) of each cultivar is given in parentheses; $2.54 \mathrm{~cm}=1.0 \mathrm{inch}$.

\begin{tabular}{|c|c|c|c|c|c|c|}
\hline $\begin{array}{l}\text { Treatment } \\
\text { [a.i. mg.L-1 }(\mathrm{ppm})]\end{array}$ & $\begin{array}{c}\text { 'Aladdin's } \\
\text { Dazzle' } \\
\text { (14-16 cm) }\end{array}$ & $\begin{array}{l}\text { 'Best Seller' } \\
(12-14 \mathrm{~cm})\end{array}$ & $\begin{array}{c}\text { 'Royal } \\
\text { Dream' } \\
(14-16 \mathrm{~cm}) \\
\end{array}$ & $\begin{array}{c}\text { 'Royal } \\
\text { Parade' } \\
(14-16 \mathrm{~cm})\end{array}$ & $\begin{array}{c}\text { 'Royal } \\
\text { Perfume' } \\
(14-16 \mathrm{~cm}) \\
\end{array}$ & $\begin{array}{c}\text { 'Salmon } \\
\text { Classic' } \\
(14-16 \mathrm{~cm})\end{array}$ \\
\hline Control & $80 a^{z}$ & $71 \mathrm{a}$ & $53 \mathrm{a}$ & $59 \mathrm{a}$ & $68 \mathrm{a}$ & $61 \mathrm{a}$ \\
\hline \multicolumn{7}{|l|}{ Paclobutrazol } \\
\hline 50 & $77 \mathrm{ab}$ & $65 \mathrm{bcd}$ & $54 \mathrm{a}$ & $52 \mathrm{bc}$ & $51 \mathrm{~cd}$ & $60 \mathrm{ab}$ \\
\hline 100 & $75 \mathrm{abc}$ & $70 \mathrm{abc}$ & $47 \mathrm{~b}$ & $48 \mathrm{c}$ & $47 \mathrm{de}$ & $59 \mathrm{ab}$ \\
\hline 200 & $58 \mathrm{e}$ & $67 \mathrm{abcd}$ & $44 \mathrm{bc}$ & $42 \mathrm{~d}$ & $42 \mathrm{efg}$ & $58 \mathrm{ab}$ \\
\hline 300 & $63 \mathrm{de}$ & $62 \mathrm{de}$ & $35 \mathrm{de}$ & $36 \mathrm{e}$ & $39 \mathrm{fgh}$ & $57 \mathrm{ab}$ \\
\hline \multicolumn{7}{|l|}{ Uniconazole } \\
\hline 2.5 & $46 \mathrm{f}$ & $59 \mathrm{e}$ & $40 \mathrm{~cd}$ & $36 \mathrm{e}$ & $43 \mathrm{ef}$ & $54 \mathrm{bc}$ \\
\hline 5.0 & $40 \mathrm{gh}$ & $46 \mathrm{f}$ & $28 \mathrm{f}$ & $34 \mathrm{ef}$ & 37 ghi & $48 \mathrm{c}$ \\
\hline 7.5 & $45 \mathrm{fg}$ & $44 \mathrm{f}$ & $31 \mathrm{ef}$ & $29 \mathrm{f}$ & $36 \mathrm{hi}$ & $41 \mathrm{~d}$ \\
\hline 10.0 & $34 \mathrm{~h}$ & $42 \mathrm{f}$ & $22 \mathrm{~g}$ & $30 \mathrm{f}$ & $32 \mathrm{i}$ & $38 \mathrm{~d}$ \\
\hline \multicolumn{7}{|l|}{ Ancymidol } \\
\hline 11 & $77 \mathrm{ab}$ & $70 \mathrm{ab}$ & $49 \mathrm{ab}$ & $54 \mathrm{ab}$ & $59 \mathrm{~b}$ & $62 \mathrm{a}$ \\
\hline 22 & $69 \mathrm{~cd}$ & 64 cde & $47 \mathrm{~b}$ & $54 \mathrm{ab}$ & $52 \mathrm{~cd}$ & $61 \mathrm{ab}$ \\
\hline 33 & $76 \mathrm{bc}$ & $63 \mathrm{de}$ & $46 \mathrm{~b}$ & $53 \mathrm{bc}$ & $55 \mathrm{bc}$ & $59 \mathrm{ab}$ \\
\hline
\end{tabular}

${ }^{\mathrm{z}}$ Mean separation within columns by Duncan's multiple range test $(P \leq 0.05)$. Values are means of five replications (plants).

other LA-hybrid cultivars.

The number of flower buds and the total number of leaves varied by cultivar, but PGR treatments had no significant effect (data not shown). In general, plant quality was commercially acceptable in all cultivars. There were few aborted buds $(<10 \%)$, and no treatment effect was observed. The size of flower buds or open flowers was not affected by PGR treatments in any cultivar (data not presented). Very little lower leaf yellowing $(<3 \%$ of leaves in LA-hybrid cultivars, and $<10 \%$ in oriental cultivars) was evident in control plants. Slight increases in the percentage leaf yellowing was observed in uniconazole treated plants of 'Aladdin's Dazzle', 'Royal Dream', and 'Royal Perfume' of LA-hybrid group, and 'Aubade' and 'Sissi' of the oriental group. Paclobutrazol treated plants of 'Aubade', 'Muscadet', 'Sissi', and 'Tom Pouce' also showed a slight increase in leaf yellowing. The extent of leaf yellowing, however, did not exceed $8 \%$ (percentage from total leaves) in the case of LAhybrids, and $15 \%$ in the case of oriental hybrids with any treatment.

Within the concentration ranges used in the study, paclobutrazol and uniconazole were effective for height control in all cultivars of both groups of hybrid lilies except 'Salmon Classic' (Tables 1 and 2). Ancymidol was the least effective product, and gave very little height reduction even at the highest rate used $\left(33 \mathrm{mg} \cdot \mathrm{L}^{-1}\right)$. Both
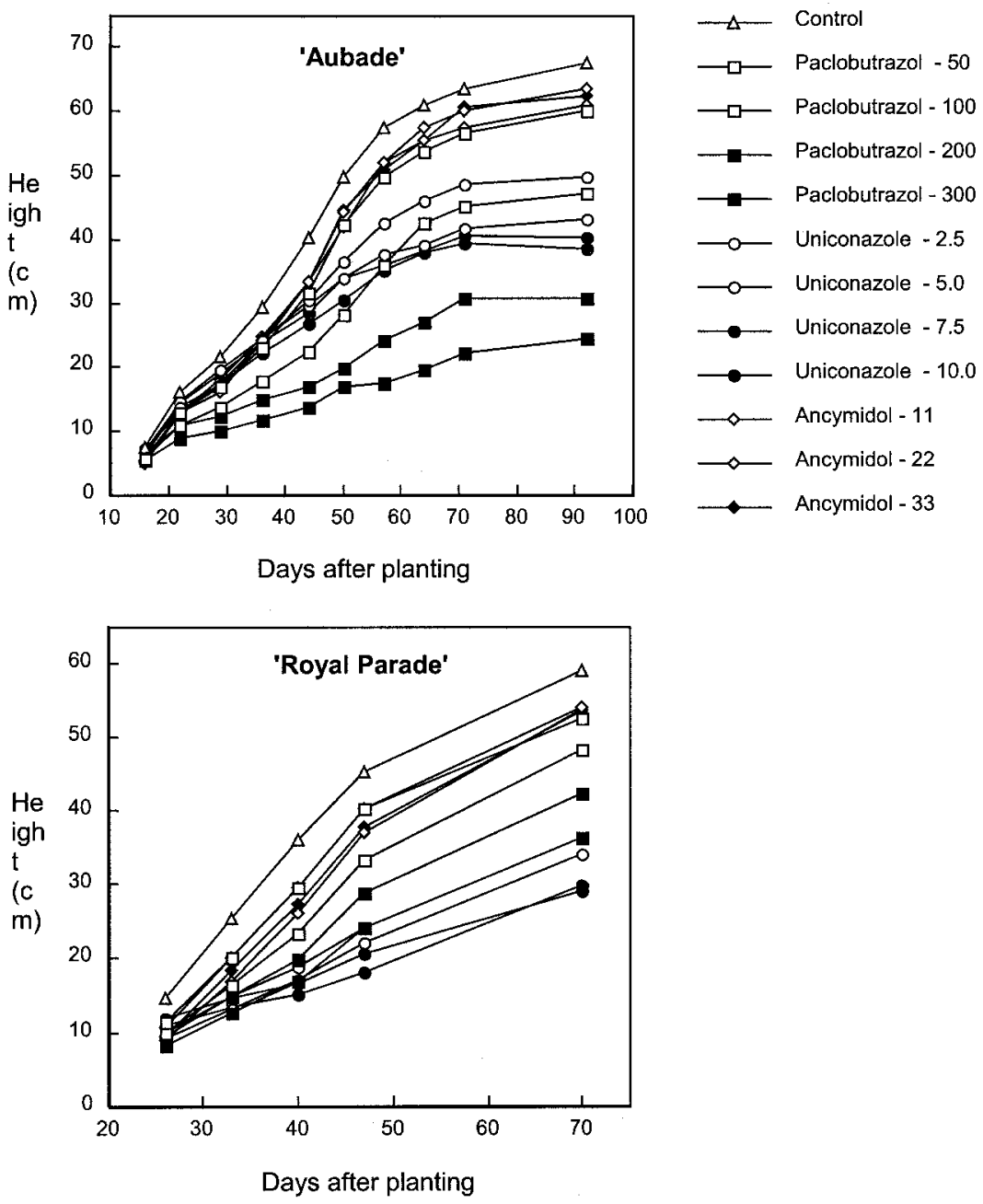

Fig. 1. Changes in plant height of oriental hybrid lily 'Aubade' and LA-hybrid lily 'Royal Parade' treated with 1 -min bulb dip containing various rates [a.i. $\mathrm{mg} \cdot \mathrm{L}^{-1}$ (ppm)] of paclobutrazol (Bonzi), uniconazole (Sumagic), and ancymidol (A-Rest) (1999 experiments). Each point is a mean of five replications (plants); $2.54 \mathrm{~cm}=1.0$ inch. 
Table 3. Effects of 1-min bulb dip in paclobutrazol (Bonzi), uniconazole (Sumagic), and ancymidol (A-Rest) on plant height (in centimeters, measured from pot rim to top of plant) of six oriental hybrid lily cultivars at flowering (2000 experiment). Bulb size (circumference) of each cultivar is given in parentheses; $2.54 \mathrm{~cm}=1.0 \mathrm{inch}$.

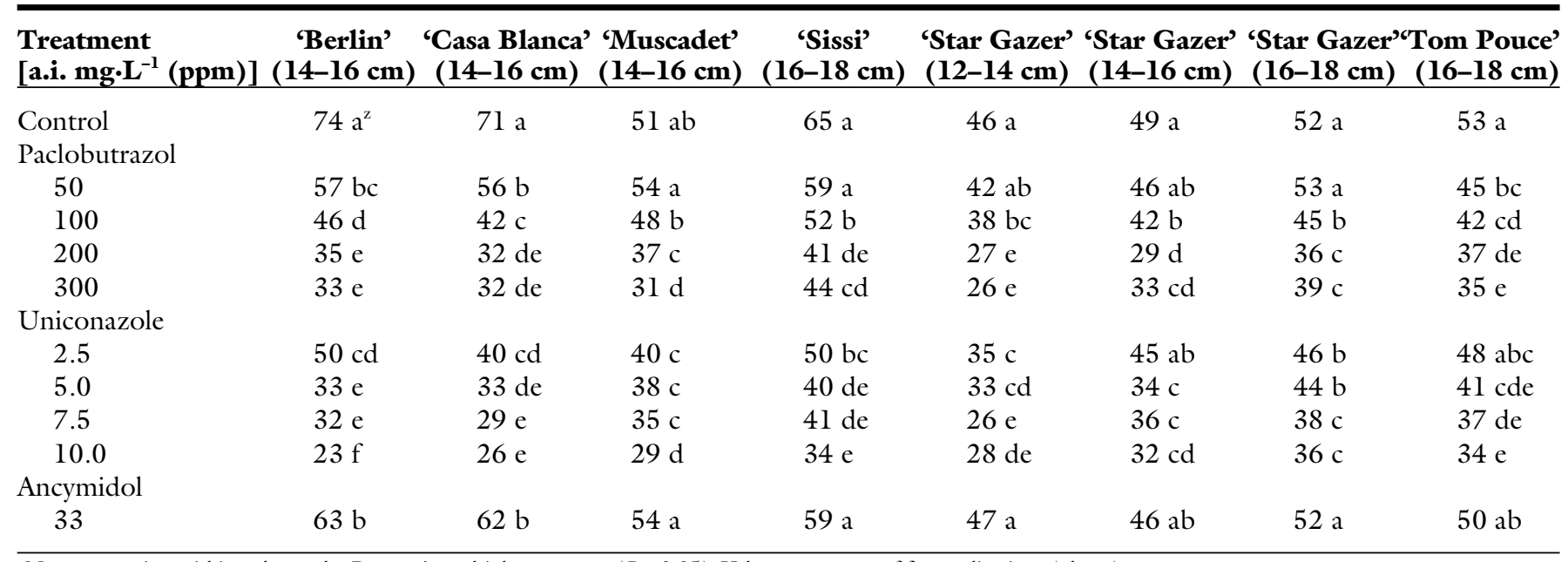

${ }^{\mathrm{z}}$ Mean separation within columns by Duncan's multiple range test $(P \leq 0.05)$. Values are means of five replications (plants).

paclobutrazol and uniconazole treatments produced a broad range of plant heights within the concentrations used. Remarkable differences in effectiveness between cultivars were evident for both growth regulators. For example, $300 \mathrm{mg} \cdot \mathrm{L}^{-1}$ paclobutrazol caused $44 \%$ height reduction in 'Royal Perfume' compared to only $7 \%$ height reduction in 'Salmon Classic'. On an active ingredient basis, uniconazole was more effective than paclobutrazol. In many cultivars, the level of height reduction caused by higher concentrations of uniconazole (e.g., 7.5 and $10.0 \mathrm{mg} \cdot \mathrm{L}^{-1}$ ) would be considered excessive, if one assumes an acceptable plant height of $40 \mathrm{~cm}$ (16 inches, not including the pot).

Weekly height measurements showed that distinct differences existed in the growth patterns between oriental and LA-hybrid lilies. Figure 1 illustrates weekly crop height of 'Aubade' which was typical of the oriental hybrids used, and 'Royal Parade' which was typical of the LA-hybrids used. In general, orientals exhibited a sustained or increasing growth rate during the first part of the crop, followed by a sharp plateau (typically after attainment of the visible bud stage), where little additional growth occurred. In contrast, the LA-hybrids did not show a plateau growth pattern, and plants continued to elongate until flowering. In both oriental and LAhybrids, effective PGR treatments reduced the rate of stem elongation beginning from early stages as evidenced by the reduction of the slope of the crop height curve.

Hortlechnology • July-September 2002 12(3)
2000 Experiments. Bulb-dip treatments did not affect the number of days for shoot emergence in any cultivar. In oriental group, control plants of 'Berlin', 'Casa Blanca', 'Muscadet', 'Sissi', 'Star Gazer' (12 to $14 \mathrm{~cm}$ ), 'Star Gazer' (14 to $16 \mathrm{~cm}$ ), 'Star Gazer' ( 16 to $18 \mathrm{~cm}$ ), and 'Tom Pouce' flowered 70, 78, 74, 84, 79, 79,78 , and $76 \mathrm{DAP}$, respectively. Up to $4 \mathrm{~d}$ of delay in flowering date occurred with certain PGR treatments in 'Berlin' (10.0 mg. $\mathrm{L}^{-1}$ uniconazole), 'Muscadet' (300 mg. $\mathrm{L}^{-1}$ paclobutrazol), 'Casa Blanca' (200 and 300 $\mathrm{mg} \cdot \mathrm{L}^{-1}$ paclobutrazol, and $10.0 \mathrm{mg} \cdot \mathrm{L}^{-1}$ uniconazole), and 'Star Gazer' (12 to $14 \mathrm{~cm})\left(200\right.$ and $300 \mathrm{mg} \cdot \mathrm{L}^{-1}$

Table 4. Effects of 1-min bulb dip in paclobutrazol (Bonzi), uniconazole (Sumagic), and ancymidol (A-Rest) on plant height (in centimeters, measured from pot rim to top of plant) of four LA-hybrid lily cultivars at flowering (2000 experiment). Bulb size (circumference) of each cultivar is given in parentheses; $2.54 \mathrm{~cm}=1.0$ inch.

\begin{tabular}{|c|c|c|c|c|}
\hline $\begin{array}{l}\text { Treatment } \\
{\left[\text { a.i. } \text { mg.L }^{-1}(\mathbf{p p m})\right]}\end{array}$ & $\begin{array}{c}\text { 'Cebeco } \\
\text { Dazzle' } \\
(14-16 \mathrm{~cm})\end{array}$ & $\begin{array}{c}\text { 'Royal } \\
\text { Parade' } \\
(12-14 \mathrm{~cm})\end{array}$ & $\begin{array}{c}\text { 'Royal } \\
\text { Perfume' } \\
(14-16 \mathrm{~cm})\end{array}$ & $\begin{array}{c}\text { 'Salmon } \\
\text { Classic' } \\
(12-14 \mathrm{~cm}) \\
\end{array}$ \\
\hline Control & $77 a^{z}$ & $57 \mathrm{a}$ & $53 a$ & $58 \mathrm{a}$ \\
\hline \multicolumn{5}{|l|}{ Paclobutrazol } \\
\hline 50 & $63 \mathrm{~b}$ & $43 \mathrm{~b}$ & $34 \mathrm{c}$ & $54 \mathrm{ab}$ \\
\hline 100 & $55 \mathrm{c}$ & $36 c$ & $28 \mathrm{~d}$ & $56 \mathrm{a}$ \\
\hline 200 & $42 \mathrm{~d}$ & $33 \mathrm{~cd}$ & $24 \mathrm{e}$ & $54 \mathrm{ab}$ \\
\hline 300 & $39 \mathrm{~d}$ & $29 \mathrm{de}$ & $22 \mathrm{ef}$ & $50 \mathrm{~b}$ \\
\hline \multicolumn{5}{|l|}{ Uniconazole } \\
\hline 2.5 & $31 \mathrm{e}$ & $25 \mathrm{ef}$ & $24 \mathrm{e}$ & $34 \mathrm{c}$ \\
\hline 5.0 & 27 ef & $23 \mathrm{f}$ & $22 \mathrm{ef}$ & $32 \mathrm{c}$ \\
\hline 7.5 & $22 \mathrm{f}$ & $24 \mathrm{f}$ & $20 \mathrm{ef}$ & $29 \mathrm{c}$ \\
\hline 10.0 & $23 \mathrm{f}$ & $19 \mathrm{~g}$ & $22 \mathrm{ef}$ & $31 \mathrm{c}$ \\
\hline \multicolumn{5}{|l|}{ Ancymidol } \\
\hline 33 & $63 \mathrm{~b}$ & $45 \mathrm{~b}$ & $39 \mathrm{~b}$ & $53 \mathrm{ab}$ \\
\hline
\end{tabular}

${ }^{\mathrm{z}}$ Mean separation within columns by Duncan's multiple range test $(P \leq 0.05)$. Values are means of five replications (plants). paclobutrazol). In the LA-hybrid group, control plants of 'Cebeco Dazzle', 'Royal Parade', 'Royal Perfume', and 'Salmon Classic' reached anthesis at $64,59,60$, and $50 \mathrm{DAP}$, respectively. In 'Cebeco Dazzle' and 'Royal Parade', $10.0 \mathrm{mg} \cdot \mathrm{L}^{-1}$ uniconazole caused an 8-d delay in flowering while lower concentrations of uniconazole caused a 2 - to 4 -d delay. Paclobutrazol did not cause any significant flowering delay in any LAhybrid cultivar.

As in the first years' experiment, the number of flower buds and total number of leaves varied by cultivar, but PGR treatments had no significant effect (data not shown). Overall plant 
Table 5. Effect of bulb circumference on percentage height reduction (compared to the control) of 'Star Gazer' lily plants after dipping $1 \mathrm{~min}$ in paclobutrazol (Bonzi), uniconazole (Sumagic), and ancymidol (A-Rest) before planting (2000 experiment); $2.54 \mathrm{~cm}=1.0 \mathrm{inch} ; 1 \mathrm{mg} \cdot \mathrm{L}^{-1}=1 \mathrm{ppm}$.

\begin{tabular}{|c|c|c|c|}
\hline \multirow{2}{*}{$\begin{array}{l}\text { Treatment } \\
{\left[\text { a.i. } \mathbf{~ m g} \cdot \mathbf{L}^{-1}(\mathrm{ppm})\right]}\end{array}$} & \multicolumn{3}{|c|}{ Bulb circumference $(\mathrm{cm})$} \\
\hline & $12-14$ & $14-16$ & 16-18 \\
\hline Control & --- & --- & --- \\
\hline \multicolumn{4}{|l|}{ Paclobutrazol } \\
\hline 50 & 10 & 5 & -2 \\
\hline 100 & 17 & 14 & 14 \\
\hline 200 & 42 & 41 & 31 \\
\hline 300 & 43 & 33 & 26 \\
\hline \multicolumn{4}{|l|}{ Uniconazole } \\
\hline 2.5 & 24 & 7 & 11 \\
\hline 5 & 27 & 30 & 15 \\
\hline 7.5 & 44 & 25 & 28 \\
\hline 10 & 40 & 35 & 31 \\
\hline \multicolumn{4}{|l|}{ Ancymidol } \\
\hline 33 & -2 & 6 & 0 \\
\hline
\end{tabular}

quality was good in all cultivars. There were few aborted buds $(<10 \%)$, and no treatment effects were apparent except 7.5 and $10.0 \mathrm{mg} \cdot \mathrm{L}^{-1}$ uniconazole in 'Cebeco Dazzle' where $50 \%$ of buds aborted. The size of flower buds or open flowers was not affected by PGR treatments in any cultivar. Very little lower leaf yellowing $(<5 \%$ of leaves in both oriental and LA-hybrid cultivars) was evident in both control and treated plants with the only exception of 7.5 and $10.0 \mathrm{mg} \cdot \mathrm{L}^{-1}$ uniconazole treatments in 'Cebeco Dazzle', in which $15 \%$ of leaves were yellow.

Uniconazole and paclobutrazol effectively reduced height in all the cultivars tested in year 2000 experiments (Tables 3 and 4). Overall, plants in most of the cultivars (control as well as PGR-treated ones) were shorter in 2000 compared to 1999 . Uniconazole was the most effective chemical for height reduction on the basis of absolute concentration of the chemical. As in year 1 , excessive height reduction occurred with higher doses of both uniconazole and paclobutrazol in several cultivars.

Bulb size significantly affected the response to PGR dips, as seen with the cultivar 'Star Gazer' (Table 5). While all sizes of 'Star Gazer' bulbs responded to paclobutrazol and uniconazole dips, growth inhibition was proportionally greater in the smaller bulbs. For example, in the $300 \mathrm{mg} \cdot \mathrm{L}^{-1}$ paclobutrazol treatment, plant height was 26,33 , and $39 \mathrm{~cm}(10.2,13.0$, and 15.4 inches $)$ for $12-$ to $14-\mathrm{cm}, 14-$ to $16-\mathrm{cm}$, and 16- to $18-\mathrm{cm}$ bulbs respectively, but the percentage height reduction (relative to the control in each bulb size) was $43 \%, 33 \%$, and $26 \%$, respectively.

\section{Discussion}

While it has long been known that preplant bulb dips in PGR can be effective for height control in lilies, newer active ingredients, new cultivars, and new classes of lilies have necessitated a reexamination of this technique for height control. The present study indicates that preplant bulb dips in paclobutrazol or uniconazole can be an effective method for height control in numerous cultivars of oriental and LA-hybrid lilies. The response to a given concentration of PGR varied significantly across cultivars. In general, oriental cultivars tended to require higher concentrations of active ingredient than LAhybrid cultivars to elicit the same degree of height reduction. The difference in cultivar response is a known problem with other PGR application methods (Jiao et al., 1990), therefore, as with sprays or drenches, evaluation of each cultivar for optimum PGR dip rate is essential before adapting this method for large scale commercial practice. Within an experimental year, the treatment effects within a given cultivar were quite uniform, and in our opinion, the uniformity was within the range of commercial acceptability.

The concentration of the dipping solution and the duration of the dip are the two major factors that determine the amount of active ingredient taken up by the bulb during a dip treatment, which in turn determines the effectiveness of treatment. The ranges of concentrations of active ingredients we used with $1-\mathrm{min}$ bulb dips (50 to $300 \mathrm{mg} \cdot \mathrm{L}^{-1}$ paclobutrazol and 2.5 to $10.0 \mathrm{mg} \cdot \mathrm{L}^{-1}$ uniconazole) were adequate while the concentrations of ancymidol used (11 to 33 $\mathrm{mg} \cdot \mathrm{L}^{-1}$ ) were not adequate, assuming a final target plant height of $40 \mathrm{~cm}$ (not including the pot). Among the three PGRs used, uniconazole was the most effective for height reduction on the basis of absolute active ingredient concentration. Previous studies with lilies have shown that uniconazole is required in lower concentrations than ancymidol for similar degree of height control when applied as a drench (Bailey and Miller, 1989).

Effective durations of bulb dips for lilies as short as $2 \mathrm{~s}$ (Lewis and Lewis 1981, Gilbertz and Lewis 1990) or as long as 12 h (Parivar et al., 1985; Simmonds and Cumming, 1977) have been reported in the literature. The increase in dipping duration seems to produce significant effects only at lower concentrations where extra time may increase the absorption of the chemical to the bulb (Parivar et al., 1985). We found no significant differences in height control between $1 \mathrm{~min}$ and $5 \mathrm{~min}$ dip treatments within the concentration ranges used (data not shown). Other possible variables that may affect the amount of material absorbed are the size of the bulb and the dryness of the bulb at the time of treatment. Bulb size significantly affects response relative to a given PGR dip treatment (Table 5).

Variable effects of PGR treatments on flowering date, bud count, flower size, and leaf quality in lilies have been reported in the literature. The general trend, however, is that higher rates of PGR tending to delay flowering, reduce the number of flowers, and increase lower leaf yellowing. In this experiment, we observed significant effects of PGR treatments on flowering date, bud count or leaf yellowing only with the highest concentrations of uniconazole or paclobutrazol. In those occasions, the height reduction was also excessive for a commercially acceptable crop.

A comparison of plant height data for each cultivar shows that sometimes the effectiveness of a given PGR treatment varied between the two years of the experiment. In general, plants of most of the cultivars were shorter in 
2000 than in 1999. This was true for both control and PGR-treated plants. Differences still existed when the rate of height reduction was calculated based on the control plant height. For example, the percentage height reduction caused by $300 \mathrm{mg} \cdot \mathrm{L}^{-1}$ paclobutrazol treatment in 1999 versus 2000 were $58 \%$ versus $45 \%$, 63\% versus $68 \%, 65 \%$ versus $67 \%$, and $55 \%$ versus $66 \%$ for 'Berlin', 'Sissi', 'Star Gazer', and 'Tom Pouce', respectively. This variability may be due to the yearly differences of the bulb itself (e.g. maturity, amount of reserves, length of cold treatment) or the differences in environmental conditions during forcing. These factors are not unique to the bulb dip method of height control, indeed they represent more general challenges of growing floricultural crops. Graphical tracking techniques (Fisher et al., 1998) can also provide useful tools to help growers surmount these problems.

The obvious disadvantage of preplant bulb dips is that they are applied well before the grower knows the need for height control, although tall cultivars will probably always benefit from growth regulation. Another effective strategy might be to use a low, partially effective dip treatment to reduce stem elongation at initial stages, and then apply foliar sprays as the crop develops. The weekly height measurements in the 1999 experiment showed that Oriental hybrid lily cultivars attain most of their height during initial phases of forcing, and bulb dip treatments were effective in controlling this stem growth beginning from very early stages. In such cultivars, a relatively long-lasting PGR effect with dips can be modified with additional, short-term control with a foliar spray.

\section{Literature cited}

Bailey, D.A. and W.B. Miller 1989. Response of oriental hybrid lilies to ancymidol and uniconazole. HortScience 24:519

Blom, T.J., M.J. Tsujita, and G.L. Roberts. 1995. Far-red at end of day and reduced irradiance affect plant height of easter and asiatic hybrid lilies. HortScience 30:1009-1012.

Choi, J.M., J.J. Choi, H.J. Chung, and J.S. Choi. 1998. Growth of oriental hybrid lily 'Star Gazer' affected by application method and concentration of uniconazole in pot plant production. J. Kor. Soc. Hort. Sci. 39:776-779 (in Korean).

Erwin, J.E. and R.D. Heins. 1990. Temperature effects on lily development rate and morphology from the visible bud stage until anthesis. J. Amer. Soc. Hort. Sci. 115:644-646

Fisher, P.R., R.D. Heins, B. Liu, and L. Bilodeau. 1998. Tracking oriental and hybrid lilies. Greenhouse Grower 16:39-40.

Gilbertz, D.A. and A.J. Lewis. 1990. Effect of planting-date and application method on ancymidol response of hybrid lilies. Sci. Hort. 45:159-165.

Holcomb, J.E., K.M. Olson, and N. Khoury. 1991. Comparison of growth retardant application methods for hybrid lily height control (Lilium $\times$ bybrida). PGRSA Quarterly 19:217-221.

Jiao, J., X. Wang, and M.J. Tsujita. 1990. Comparative effects of uniconazole drench and spray on shoot elongation of hybrid lilies. HortScience 25:1244-1246.

Larson, R.A., C.B. Thorne, R.R. Milks, Y.M. Isenberg, and L.D. Brisson. 1987. Use of ancymidol bulb dips to control stem elongation of easter lilies grown in a pine bark medium. J. Amer. Soc. Hort. Sci. 112:773-777.
Lewis, A.J. and D.A. Gilbertz. 1987. Hybrid lily response to various methods of ancymidol application. Acta Hort. 205:237-240.

Lewis, A.J. and J.S. Lewis. 1980. Response of Lilium longiflorum to ancymidol bulbdips. Sci. Hort. 13:93-97.

Lewis, A.J. and J.S. Lewis. 1981. Improving ancymidol efficiency for height control of Easter lily. HortScience 16:89-90.

Lewis, A.J. and J.S. Lewis. 1982. Height control of Lilium longiflorum Thunb. 'Ace' using ancymidol bulb-dips. HortScience 17:336-337.

Liu, B. and R.D. Heins. 1995. Stem elongation response of 'Stargazer' oriental lily to bulb dips in uniconazole. HortScience 30:852 (abstr.).

Parivar, F., J.E. Preece, and G.D. Coorts. 1985. The effects of ancymidol concentrations and application methods on cultivars of mid-century hybrid lily. J. Hort. Sci. 60:263-268

Sachs, R.W., A.M. Kofranek, and W.P. Hackett. 1976. Evaluating new pot plant species. Florist Rev. 159(4116):35-36, 8084.

Simmonds, J.A. and B.G. Cumming. 1977. Bulb-dip application of growth-regulating chemicals for inhibiting stem elongation of 'Enchantment' and 'Harmony' lilies. Sci. Hort. 6:71-81.

Simmonds, J.A. and B.G. Cumming. 1978. The interaction of a dormancy-breaking cold treatment, ancymidol, and ethephon in relation to stem elongation and flower production of Lilium cultivars. Sci. Hort. 8:57-64. 